\title{
Allostasis as a conceptual framework linking bipolar disorder and addiction
}

\section{Mauro Pettorruso ${ }^{1}{ }^{*}$, Luisa De Risio ${ }^{1}$, Marco Di Nicola ${ }^{1}$, Giovanni Martinotti ${ }^{2}$, Gianluigi Conte ${ }^{1}$ and Luigi Janiri ${ }^{1}$}

${ }^{1}$ Department of Neuroscience, Institute of Psychiatry and Clinical Psychology, Catholic University of Sacred Heart, Rome, Italy

${ }^{2}$ Department of Neuroscience and Imaging, Institute of Psychiatry, "G. d'Annunzio" University of Chieti-Pescara, Chieti, Italy

\section{Edited by:}

Alain Dervaux, Centre Hospitalier

Sainte-Anne, France

Reviewed by:

Zachary A. Rodd, Indiana University School of Medicine, USA

Mauro Ceccanti, Sapienza University of Rome, Italy

*Correspondence:

Mauro Pettorruso, Day Hospital di Psichiatria Clinica e

Farmacodipendenze, Policlinico "A. Gemelli," Largo A. Gemelli 8, Rome 00168, Italy

e-mail: mauro.pettorruso@hotmail.it
Bipolar disorders (BDs) and addictions constitute reciprocal risk factors and are best considered under a unitary perspective. The concepts of allostasis and allostatic load (AL) may contribute to the understanding of the complex relationships between $\mathrm{BD}$ and addictive behaviors. Allostasis entails the safeguarding of reward function stability by recruitment of changes in the reward and stress system neurocircuitry and it may help to elucidate neurobiological underpinnings of vulnerability to addiction in BD patients. Conceptualizing BD as an illness involving the cumulative build-up of allostatic states, we hypothesize a progressive dysregulation of reward circuits clinically expressed as negative affective states (i.e., anhedonia). Such negative affective states may render BD patients more vulnerable to drug addiction, fostering a very rapid transition from occasional drug use to addiction, through mechanisms of negative reinforcement. The resulting addictive behavior-related ALs, in turn, may contribute to illness progression. This framework could have a heuristic value to enhance research on pathophysiology and treatment of BD and addiction comorbidity.

Keywords: bipolar disorders, addiction vulnerability, allostasis and allostatic load, comorbidity, hedonic tone and anhedonia, dopaminergic system, reward system, CRF/HPA axis and stress system

\section{INTRODUCTION}

Bipolar disorder (BD) is a severe, often chronic condition with lifetime prevalence rates of up to $6.5 \%$ for bipolar spectrum disorders in the general population (1). BD patients frequently report co-occurring substance-use disorders (SUDs) and behavioral addictions (1-5). The rates of alcohol and other SUDs are significantly higher in subjects with BD than in the general population $(1,6)$. The co-occurrence of $\mathrm{BD}$ and addiction has important clinical implications $(3,7)$. Bipolar patients with comorbid conditions present with a more severe course of illness (8), characterized by an overall worse clinical picture (9), poorer treatment outcome (10-12), higher suicidality (13), and mortality (14).

Several studies have aimed to identify the endophenotypical features predisposing to the development of addiction in the general population, as well as in the context of BD. These studies focused on genetic vulnerability, impulsive traits, and decision-making impairment (15-19).

The aim of this paper is to present the possible contribution of the concept of allostasis as a framework linking $\mathrm{BD}$ and addiction. We hypothesize that the concepts of allostasis and allostatic load (AL) may contribute to the understanding of the complex relationships between $\mathrm{BD}$ and addictive behaviors (20-22). Allostasis entails the safeguarding of reward function stability by recruitment of changes in the reward and stress system neurocircuitry

Abbreviations: AL, allostatic load; BD, bipolar disorder; CRF, corticotropinreleasing factor; GD, gambling disorder; HPA, hypothalamic-pituitaryadrenocortical (axis); SUD, substance-use disorder.
(21) and it may help to elucidate neurobiological underpinnings of vulnerability to addiction in BD patients.

\section{METHODS}

Computerized database, i.e., PubMed, Psycinfo, Cochrane Library were searched using the following terms: "allostasis," "AL," "reward," "hedonic tone," "stress system" cross-referenced with "BD," "addiction," and "SUDs." The results of this search are presented in this article, and examined in light of a unifying hypothesis with a potential heuristic value to inform and provide direction to future research in this intriguing area.

\section{RELEVANCE OF ALLOSTASIS IN BD AND ADDICTION FIELD BIPOLAR DISORDERS}

Bipolar disorders is a complex and multifactorial disease, with genetic and environmental factors contributing to its clinical expression (23). BD can also be conceptualized as an illness involving the cumulative build-up of allostatic states, whereas AL progressively increases as stressors and mood episodes occur over time (24). Indeed, it has been postulated that mood episodes function as allostatic states, generating a load that is responsible for illness progression commonly seen in $\mathrm{BD}(25,26)$. AL may contribute to a better understanding of $\mathrm{BD}$, particularly of inter-episodic phenomena such as vulnerability to stress, cognitive symptoms (26), and higher physical comorbidity rates (24). BD patients present with alterations in major mediators of AL. They exhibit for instance, persistent dysregulation of the hypothalamic-pituitaryadrenocortical (HPA) axis, circadian rhythm disturbances, altered immunity as well as pro-inflammatory and oxidative stress states 
[please refer to the review Kapczinski et al. (24)]. Neurotrophic factors play an important role in maintaining a physiological brain function. They have been shown to be modulated by environmental events in various psychopathological conditions (27), and their role has been confirmed also in pathophysiology and staging of BD (28-31).

These alterations are greater during the acute stages of the disease, but remain sub-threshold even during remission (24). When mediators of allostasis - essential for brain functioning and protection - are driven by mechanisms of homeostatic dysregulation, they act in excess and damage brain tissue $(32,33)$, which is particularly vulnerable to the harmful effects of the AL [i.e., oxidative stress (34)]. Impairment in the stress response has been acknowledged as a core feature of BD clinical expression, as well as having a central role in the concept of AL (23). Although the exact mechanisms, by which stress exerts its effect on the brain, remain largely unknown, the HPA axis is one of the main stress response systems activated with the objective to maintain stress adaptation for as long as it is necessary (23). The HPA axis is clearly altered in mood disorders, as well as in BD (35-38). Glucocorticoids play an important role in the process whereby the mediators of allostasis interact with neurotransmitter systems and brain peptides resulting in neuroplastic alterations in the hippocampus, amygdala, and prefrontal cortex $(39,40)$. The role of stress in triggering mood episodes is well established, particularly in the early stages of illness $(41,42)$. It has been hypothesized that early life stress could affect the endocrine system, producing a stable reprograming of HPA axis (43), leading to an impairment in brain area involved in emotional processing (44). Alterations in emotional processing involving amygdala circuitry and are related to BD symptoms in several ways. Evidence from amygdala-dependent tasks points to a dysregulation of amygdala-related neurocircuitry in BD patients (45). These alterations render BD patients more prone to trigger AL (23), through a greater stress vulnerability.

\section{ADDICTION}

Drug addiction can be conceptualized as a stress-surfeit disorder (46). It is characterized by the occurrence of an allostatic state in the brain reward system, reflected in a chronic deviation of reward thresholds (46-48). An allostatic state reflects a new balance, a state of chronic deviation of the regulatory system from its normal (homeostatic) operating level to a pathological (allostatic) operating level (47). From a drug addiction perspective, repeated compromised activity in the dopaminergic system and sustained activation of the corticotropin-releasing factor (CRF) system may lead to an AL that contributes significantly to the transition from occasional drug use to drug addiction $(49,50)$. This model may be applied to pathological gambling as well (51). The transition from occasional controlled drug use to loss of control is endorsed by the emergence of negative affective states, resulting from the abovementioned allostatic dysregulations (i.e., the AL), with a shift from impulsivity to compulsivity and from positive reinforcement to negative reinforcement $(49,52)$.

Addiction implies dysregulation of the brain reward system $(48,53)$. Several studies highlighted that negative affective states are a result of the alteration of neurobiological elements central to reward and stress systems $(50,54,55)$, in brain areas such as the ventral striatum and the extended amygdala $(56,57)$. In addition to the reduction of dopaminergic and opioidergic functioning, dysregulation of reward is also mediated by the activation of brain stress systems (i.e., CRF), in the areas of the extended amygdala (57). Stress system alterations have been observed in both the acute and chronic phases of addiction, and seem to play a role in determining reward dysregulation $(48,54)$. Acute withdrawal raises the threshold for reward, leads to an increase in dysphoric symptoms as well as an increase of CRF levels in the amygdala (49, 58). These changes result from sensitization of the brain stress system in response to the phenomena of abstinence, and persist for a long period of time following cessation of drug intake [protracted withdrawal (59)]. Protracted withdrawal symptoms are related to the compulsivity characterizing addictive disorders, and are factors involved in determining relapse. In addition to CRF, other mediators (norepinephrine, dynorphin, and neuropeptide $\mathrm{Y}$ ) have been investigated and found to play a role in the transition from impulsivity to compulsivity $(58,60)$. As a whole, these elements constitute the brain stress system of the extended amygdala, a counter-adaptive system that interacts with the reward system and determine its reduced function (48).

\section{NEUROBIOLOGICAL ISSUES OF BD-SUD COMORBIDITY}

A complete review of neurobiological features in BD-SUD comorbidity is beyond the purpose of this paper. Familial and illness course characteristics of BD and addictive disorders, as well as shared underlying mechanisms suggest potentially important genetic overlap $(19,61,62)$. Preliminary findings hint at the existence of a shared genetic vulnerability for BD and SUDs (15). Johnson et al. (63) found convergent genome-wide association results for BD and SUDs. Products of one group of these genes are likely to play substantial roles in the initial and/or plasticity-related "wiring" of the brain (63). A second group of genes is the family of clock genes, implicated in the regulation of behavioral and physiological periodicity (19). Recently, a significant genetic overlap between candidate genes for both alcoholism and BD was found $(64,65)$, by using the D-box binding protein knockout mouse, a stress-reactive animal model developed consistently with allostasis and stress-surfeit theory of addiction (46).

To date, no studies have specifically investigated neuroimaging correlates in comorbid BD-SUD patients. Several studies describe putative mechanisms involved in $\mathrm{BD}$ vulnerability to addiction. Structural imaging studies in BD patients found volume reductions in prefrontal cortex [PFC (66)], which is involved in encoding incentive information (67). During Iowa gambling task (IGT), BD patients showed abnormalities in the dorsal and ventral PFC, while lateral temporal and polar regions displayed increased activation (68). Jogia et al. (69) confirmed these observations and also reported a greater activation in the anterior cingulate cortex of BD patients performing the IGT and in the insula during the n-back working memory task. Reduced functioning of the dopamine transporter (DAT) has been linked to BD (70-72). Animal models may provide insight into the role of the dopaminergic system in risk-taking behavior. Mice with reduced DAT functioning exhibit a behavioral profile consistent with manic patients and increased risk-taking behavior during a mouse version of the IGT (70). Evidence from these animal model studies and translational 
human research in $\mathrm{BD}$ subjects $(73,74)$, allows us to hypothesize that system-related change involving functioning of the dopamine system play a role in impulsive choice, risk-taking behavior, and reward, thus help guiding future studies in BD-SUD subjects.

\section{ALLOSTATIC DYSREGULATION OF REWARD MIGHT UNDERPIN BIPOLAR VULNERABILITY TO ADDICTION}

Dopaminergic mechanisms are likely to play a key role in the understanding of the pathophysiology of $\mathrm{BD}$ and the clinical phenomena of mania and depression have previously been conceptualized in terms of an increase or a decrease in dopaminergic function, respectively $(75,76)$. Also, converging lines of evidence suggest that dopamine is a key neurotransmitter mediating hedonic allostasis in drug and behavioral addictions $(49,77)$. From a neurobiological perspective, a central dopaminergic dysfunction has been widely proposed as a neurobiological correlate of anhedonia (78). Different studies suggest anhedonia as a key symptom in addictive disorders, both as part of a withdrawal syndrome and as a relevant factor involved in relapses $(51,59,79)$. In addition to dopamine, other neurotransmitters are believed to encode the hedonic experience [endogenous opioids, serotonin (80)], while long-lasting alterations involving cue-induced craving and relapse are thought to result from neuroplastic changes in glutamatergic circuitry (81-83).

Several studies provide support for reward dysregulation accounts in $\operatorname{BD}(16,18,45,69,84-95)$ (Table 1), characterizing neural dynamics underlying inter-temporal reward processing (90). Possibly emotional dysregulation present in BD is related to hypersensitivity to reward-relevant stimuli (93). Impulsive and unsafe decision-making in $\mathrm{BD}$ is linked to decreased sensitivity to emotional contexts involving rewards or punishments, possibly reflecting altered appraisal of prospective gains and losses associated with certain behaviors (89). It has been proposed that anhedonia could be mediated by a change in reward sensitivity (78), which has different behavioral consequences involving either stress-related and dopaminergic processes (96). In BD, sustained allostatic states and the consequent cumulative brain damage resulting from increased AL may play a part in the occurrence of negative affective states (i.e., anhedonia) that persist even during periods of remission (84). Counter-adaptive processes, such as opponent process that are part of the normal homeostatic limitation of reward function (55) fail to return within the normal homeostatic range and are hypothesized to repeatedly drive the allostatic state [decreased dopamine and opioid peptide function, increased CRF activity (49)]. This allostatic state is hypothesized to be reflected in a chronic deviation of reward set point that is fueled, not only by dysregulation of reward circuits per se but also by recruitment of brain and hormonal stress responses.

Altered functioning of the HPA axis may hold clues to the nature of the motivational changes accompanying addiction and vulnerability to addiction (97). Pre-existing alterations in frontallimbic interactions with the HPA may reflect addiction-proneness, as shown in studies of offspring of alcohol- and drug-abusing parents (98). Alterations in the CRF/HPA axis may exert effects on the corticostriatal-limbic motivational, learning, and adaptation systems that include mesolimbic dopamine, glutamate, and gamma-amino-butyric acid (GABA) pathways (97), representing the underlying pathophysiology associated with stress-related risk of addiction.

The effects of these allostatic changes in the mesocorticolimbic brain system and in CRF/HPA axis contribute to the underlying pathophysiology associated with stress-related risk of addiction in BD (99). In BD patients, we hypothesize that the hedonic response to an acute drug administration occurs on a pre-existing allostatic dysregulation of the dopamine and CRF system. BD-related allostatic alterations in reward and stress systems thereby constitute vulnerability factors to the development of addiction in subjects exposed to occasional drug use. The failure to self-regulate these systems, determined by the collective contribution of endogenous factors linked to BD and of exogenous substances, results in an $\mathrm{AL}$ leading to a facilitated transition to drug addiction.

Dysphoria triggers drug intake, accompanied by an intense activity of the dopaminergic system and followed by a compensatory decrease in the dopaminergic system and increase in the CRF system to re-establish the allostatic set point. Such negative affective states may render BD patients more vulnerable to drug addiction, favoring a very rapid transition from occasional, recreational drug use to compulsive, pathological, drug dependence. The resulting addictive behavior-related ALs, in turn, may contribute to illness progression (Figure 1).

\section{CLINICAL IMPLICATIONS AND FUTURE PERSPECTIVES}

Converging data from addiction and BD studies suggest that these disorders involve similar allostatic processes, and allostasis can contribute to unify these disorders under a unitary perspective. In this context, the concepts of allostasis and AL provide both a pathophysiological model for the understanding of BDaddiction comorbidity and a new perspective for the development of novel therapeutic strategies for the treatment of comorbid patients $(100,101)$.

Allostatic alterations in brain reward system could render BD patients more vulnerable to drug addiction, favoring a very rapid transition from occasional, recreational drug use to compulsive, pathological, and drug dependence. This framework allows us to explain the high comorbidity rate between these disorders (2), as well as its relevance in early-onset patients $(8,102)$. Furthermore, it enables us to identify the factors of vulnerability to addiction in inter-episode periods as well (i.e., sub-threshold reward-system dysfunctions) (84). A more accurate monitoring of comorbidityrisk (103), coupled with the inclusion of specific tools for the assessment of hedonic tone, may contribute to early intervention on addiction-vulnerability factors and to initiate primary prophylaxis for substance misuse in youth suffering from BD with high-risk for addiction (104-106).

Currently, accruing evidence suggests that mood alteration episodes increase the risk of substance use $(107,108)$. Patients with dual disorders are more likely to use substances to self-regulate perceived internal factors $(109,110)$. SUD comorbidity in BD patients was preceded by greater manic symptoms in the previous period (104), as well as the persistence of depressive symptoms was associated with higher craving and increased risk to develop substance dependence $(104,108)$. Moreover, in gambling disorder (GD) patients depressive symptoms predicted gambling urges and duration (111). Allostasis framework enables us to extend 
Table 1 | Reward-system alterations and vulnerability to addiction in euthymic bipolar patients

\begin{tabular}{|c|c|c|c|c|c|}
\hline Aim & Methods & Sample & Results & Comments & Reference \\
\hline $\begin{array}{l}\text { Trait-related } \\
\text { decision- } \\
\text { making } \\
\text { impairment }\end{array}$ & $\begin{array}{l}\text { IGT, sensitivity- } \\
\text { to-punishment } \\
\text { index }\end{array}$ & $\begin{array}{l}167 \mathrm{BD}(45 \\
\text { mania, } 32 \\
\text { depressed, } 90 \\
\text { euthymic), } 150 \\
\text { HC }\end{array}$ & $\begin{array}{l}\text { Manic, depressed, and euthymic BPs selected } \\
\text { significantly more cards from the risky decks than } \\
\text { HC. BD preferred decks that yielded infrequent } \\
\text { penalties over those yielding frequent penalties. }\end{array}$ & $\begin{array}{l}\text { BD have a trait-related } \\
\text { impairment in } \\
\text { decision-making that does not } \\
\text { vary across illness phase, } \\
\text { predicted by high depressive } \\
\text { scores }\end{array}$ & (16) \\
\hline $\begin{array}{l}\text { Functional } \\
\text { brain } \\
\text { abnormalities } \\
\text { during reward } \\
\text { and working } \\
\text { memory } \\
\text { processing }\end{array}$ & $\begin{array}{l}\text { fMRI, IGT, } \\
\text { n-back task }\end{array}$ & $36 \mathrm{BD}, 37 \mathrm{HC}$ & $\begin{array}{l}\text { BD showed inefficient engagement within the } \\
\text { ventral frontopolar prefrontal cortex with } \\
\text { segregation along the medial-lateral dimension for } \\
\text { reward and working memory processing, } \\
\text { respectively. Greater activation in the anterior } \\
\text { cingulate cortex during the IGT and in the insula } \\
\text { during the n-back task. }\end{array}$ & $\begin{array}{l}\text { Over-activation in regions } \\
\text { involved in emotional arousal } \\
\text { is present even in tasks that } \\
\text { do not typically engage } \\
\text { emotional systems }\end{array}$ & (69) \\
\hline $\begin{array}{l}\text { Neural } \\
\text { correlates of } \\
\text { reward and } \\
\text { decision- } \\
\text { making }\end{array}$ & $\begin{array}{l}\text { IGT, RDMUR, } \\
\text { ERP-assessed } \\
\text { RDGT }\end{array}$ & $\begin{array}{l}13 \mathrm{BD}, 12 \\
A D H D, 25 \mathrm{HC}\end{array}$ & $\begin{array}{l}\text { BD group showed a pattern of enhanced 'learning } \\
\text { by feedback' and 'sensitivity to reward magnitude' } \\
\text { regardless of valence. This ERP pattern was } \\
\text { associated with mood and inhibitory control. } \\
\text { Reduced responses of the cingulate cortex to the } \\
\text { valence and magnitude of rewards in BD. }\end{array}$ & $\begin{array}{l}\text { Altered decision-making } \\
\text { process in } \mathrm{BD} \text { with the } \\
\text { involvement of cingulate } \\
\text { cortex }\end{array}$ & (86) \\
\hline Impulsivity & $\begin{array}{l}\text { BIS-11, stop } \\
\text { signal task, } \\
\text { delayed reward } \\
\text { task, continuous } \\
\text { performance } \\
\text { task }\end{array}$ & $\begin{array}{l}108 \text { BD1 } \\
\text { (1-year FU), } 48 \\
\text { HC }\end{array}$ & $\begin{array}{l}\text { At baseline (manic/mixed state), BD demonstrated } \\
\text { significant deficits on all three tasks. Performance } \\
\text { on the three behavioral tasks normalized upon } \\
\text { switching to depression or developing euthymia. } \\
\text { Elevated BIS-11 scores persist across phases of } \\
\text { illness. }\end{array}$ & $\begin{array}{l}\text { Impulsivity has both } \\
\text { affective-state dependent and } \\
\text { trait components in BD. }\end{array}$ & (87) \\
\hline $\begin{array}{l}\text { Dysfunctional } \\
\text { reward } \\
\text { processing }\end{array}$ & $\begin{array}{l}\text { Probabilistic } \\
\text { reward task }\end{array}$ & $18 \mathrm{BD}, 25 \mathrm{HC}$ & $\begin{array}{l}\text { BD showed a reduced and delayed acquisition of } \\
\text { response bias toward the more frequently } \\
\text { rewarded stimulus }\end{array}$ & $\begin{array}{l}\text { Dysfunctional reward learning } \\
\text { in situations requiring } \\
\text { integration of reinforcement } \\
\text { information in } \mathrm{BD}\end{array}$ & (88) \\
\hline
\end{tabular}




\section{Table 1 | Continued}

\begin{tabular}{|c|c|c|c|c|c|}
\hline Aim & Methods & Sample & Results & Comments & Reference \\
\hline $\begin{array}{l}\text { Risky decision- } \\
\text { making } \\
\text { (rewards vs } \\
\text { punishments) }\end{array}$ & $\begin{array}{l}\text { Risky } \\
\text { decision-making } \\
\text { task }\end{array}$ & $\begin{array}{l}20 \mathrm{BD}-2, \mathrm{DF} \\
20 \mathrm{HC}\end{array}$ & $\begin{array}{l}\text { The BD participants overestimated the number of } \\
\text { bad outcomes arising out of positively framed } \\
\text { dilemmas. Risky choice in BD is associated with } \\
\text { reduced sensitivity to emotional contexts that } \\
\text { highlight rewards or punishments. }\end{array}$ & $\begin{array}{l}\text { In BD, altered valuations of } \\
\text { prospective gains and losses } \\
\text { associated with behavioral } \\
\text { options. }\end{array}$ & (89) \\
\hline $\begin{array}{l}\text { Neural } \\
\text { correlates of } \\
\text { hypersensitiv- } \\
\text { ity to } \\
\text { immediate } \\
\text { reward }\end{array}$ & $\begin{array}{l}\text { (1) Two choice } \\
\text { impulsivity } \\
\text { paradigm } \\
\text { (2) Delay } \\
\text { discounting } \\
\text { task, EEG }\end{array}$ & $\begin{array}{l}\text { 1) } 32 \text { subjects } \\
\text { 2) } 32 \text { subjects }\end{array}$ & $\begin{array}{l}\text { (1) The hypomania-prone group made significantly } \\
\text { more immediate choices than the control group. } \\
\text { (2) The hypomania-prone group evidenced greater } \\
\text { differentiation between delayed and immediate } \\
\text { outcomes in early attention-sensitive (N1) and later } \\
\text { reward-sensitive (feedback-related negativity) } \\
\text { components. }\end{array}$ & $\begin{array}{l}\text { Provide support for reward } \\
\text { dysregulation accounts of BD, } \\
\text { characterizing neural } \\
\text { dynamics underlying } \\
\text { inter-temporal reward } \\
\text { processing }\end{array}$ & (90) \\
\hline $\begin{array}{l}\text { Substance } \\
\text { sensitivity and } \\
\text { sensation } \\
\text { seeking }\end{array}$ & $\begin{array}{l}\text { SCID-I, } \\
\text { SCI-SUBS }\end{array}$ & $\begin{array}{l}57 \text { BD1-SUD, } \\
47 \text { BD1, } 35 \\
\text { SUD, } 50 \text { HC }\end{array}$ & $\begin{array}{l}\text { BD + SUD and SUD have higher scores on } \\
\text { self-medication, substance sensitivity and } \\
\text { sensation seeking. No differences in reasons for } \\
\text { substance use between BD + SUD and SUD } \\
\text { (improving mood; relieving tension; alleviating } \\
\text { boredom; achieving/maintaining euphoria; } \\
\text { increasing energy). }\end{array}$ & $\begin{array}{l}\text { In BD patients, substance } \\
\text { sensitivity and sensation } \\
\text { seeking traits are possible } \\
\text { factors associated with SUD } \\
\text { development }\end{array}$ & (91) \\
\hline $\begin{array}{l}\text { Reward } \\
\text { sensitivity and } \\
\text { positive affect }\end{array}$ & $\begin{array}{l}\text { RPA; RRI; } \\
\text { BQL-BD }\end{array}$ & $90 \mathrm{BD} 1,72 \mathrm{HC}$ & $\begin{array}{l}\text { The majority of BD-1 reported avoiding at least one } \\
\text { rewarding activity as a means of preventing mania. } \\
\text { Lower quality of life related to dampening positive } \\
\text { emotions. }\end{array}$ & $\begin{array}{l}\text { People with BD-1 report } \\
\text { avoiding rewarding activities } \\
\text { and dampening positive } \\
\text { emotion }\end{array}$ & (92) \\
\hline $\begin{array}{l}\text { Neural } \\
\text { correlates of } \\
\text { hypersensitiv- } \\
\text { ity to } \\
\text { reward }\end{array}$ & $\begin{array}{l}\text { fMRI, } \\
\text { anticipation and } \\
\text { outcome reward } \\
\text { task }\end{array}$ & $21 \mathrm{BD} 1,20 \mathrm{HC}$ & $\begin{array}{l}\text { BD displayed greater ventral striatal and right-sided } \\
\text { OFC (BA 11) activity during anticipation, but not } \\
\text { outcome, of monetary reward. BD also displayed } \\
\text { elevated left-lateral OFC (BA 47) activity during } \\
\text { reward anticipation }\end{array}$ & $\begin{array}{l}\text { Elevated ventral striatal and } \\
\text { OFC activity during reward } \\
\text { anticipation as a mechanism } \\
\text { underlying predisposition to } \\
\text { hypo/mania in response to } \\
\text { reward-relevant cues. }\end{array}$ & (93) \\
\hline $\begin{array}{l}\text { Sensitivity to } \\
\text { positive and } \\
\text { negative } \\
\text { feedback }\end{array}$ & $\begin{array}{l}\text { Learning task } \\
\text { (posi- } \\
\text { tive/negative } \\
\text { feedback) }\end{array}$ & $\begin{array}{l}23 \text { BD1, } 19 \\
M D, 19 \mathrm{HC}\end{array}$ & $\begin{array}{l}\text { The quality of the last affective episode was the } \\
\text { only significant predictor. BD1 patients who last } \\
\text { experienced a manic episode learned well from } \\
\text { positive but not negative feedback, whereas BD1 } \\
\text { patients who last experienced a depressive } \\
\text { episode showed the opposite pattern }\end{array}$ & $\begin{array}{l}\text { Differences in response to } \\
\text { positive and negative } \\
\text { consequences carrying over } \\
\text { into the euthymic state are } \\
\text { related to the polarity of the } \\
\text { preceding episode }\end{array}$ & (94) \\
\hline $\begin{array}{l}\text { Motivational } \\
\text { aspects of } \\
\text { decision- } \\
\text { making in } \\
\text { relation to } \\
\text { reward and } \\
\text { punishment }\end{array}$ & IGT & $\begin{array}{l}28 \text { BD (14 } \\
\text { acute and } 14 \\
\text { remitted) } 25 \\
\text { HC }\end{array}$ & $\begin{array}{l}\text { Acute BD were characterized by the tendency to } \\
\text { make erratic choices. Low choice consistency } \\
\text { improved the prediction of acute BD beyond that } \\
\text { provided by cognitive functioning and self-report } \\
\text { measures of personality and temperament. }\end{array}$ & $\begin{array}{l}\text { Low choice consistency in BD } \\
\text { patients }\end{array}$ & (95) \\
\hline
\end{tabular}

BD, bipolar disorder; SZ, schizophrenia; HC, healthy controls; SUD, substance-use disorder; SCID-I, structured clinical interview for DSM-IV axis I disorders; SCI-SUBS, structured clinical interview for the spectrum of substance use; DF, drug-free; SHAPS, Snaith-Hamilton pleasure scale; SANS-An, scale for the assessment of negative

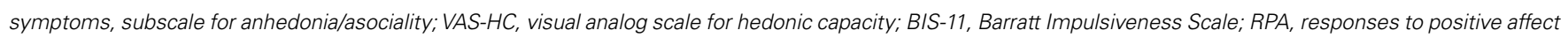

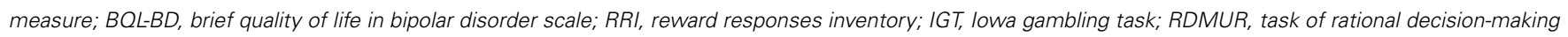

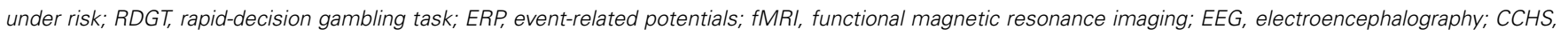
Canadian Community Health Survey-Mental Health and Well-Being; OFC, orbitofrontal cortex; BA, Brodmann area; FU, follow-up. 


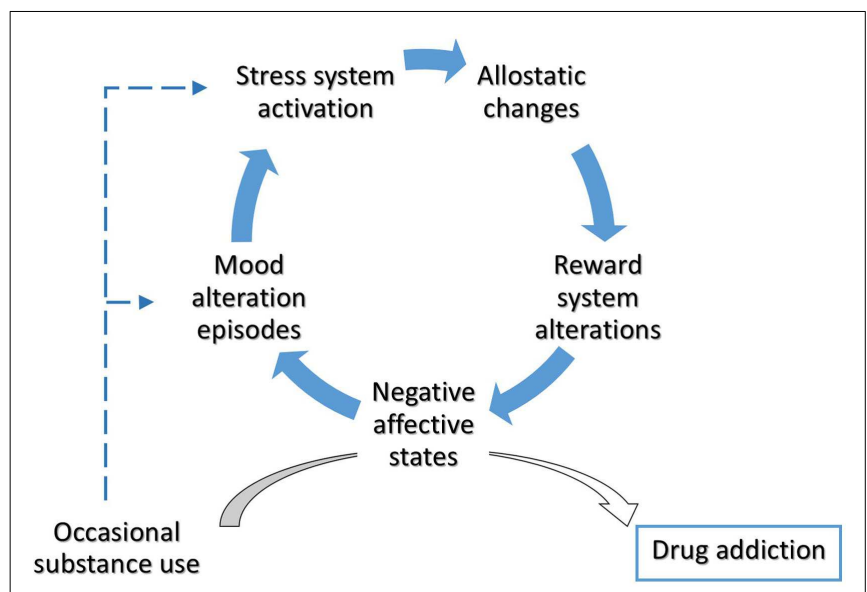

FIGURE 1 | Allostatic alterations in bipolar disorder and vulnerability to addiction. Throughout the involvement of enduring alterations in stressand reward-system, BD patients could experience a rapid transition from occasional drug use to drug addiction. The occurrence of negative affective states mediate the switch from impulsivity to compulsivity in bipolar patients. Cumulative effects of mood episodes and substance use on stress system have been hypothesized.

the self-medication theory (112) beyond the established clinical domains, increasing the understanding of the interactions between BD symptoms and substance use. For instance, euthymic bipolar patients are more likely to experience cognitive impairment (deficits in measures of executive functions, verbal learning, immediate and delayed verbal memory, abstraction, sustained attention) (113). Cannabis abuse seems to positively affect cognitive function in a BD sample (114), and it may represent an attempt to counterbalance these alterations, even though causing an increased risk of rapid cycling and an earlier onset of manic episodes $(114,115)$.

Practitioners should be particularly vigilant in monitoring for substance misuse early after the onset of mood disorders, as well as they should be aware of personality traits related to the risk of addiction, in particular antisocial and schizotypal personality disorder $(11,116)$. The existence of additional risk factors [i.e., ADHD (117)] for the development of a BDSUD comorbidity is controversial $(105,118)$. Combined with a specific role of traumatic stress as independent vulnerabilityfactor $(99,119)$, these elements contribute to the build-up of a cumulative AL. Clinicians can therefore incorporate specific therapy approaches for dual disorders (120-122) to target adherence weaknesses (123) and to enhance the effects of existing treatments.

Given the notion that exposure to stress or drugs leads to enduring changes in gene expression or activation of transcription factors, determining long-term neuroadaptation of brain functions, a promising field of future research could involve the detection of valuable markers of AL (124). In fact, markers of AL could contribute to prevention strategy $(105,116,125)$; moreover, they could improve clinical monitoring and prognostic assessment of comorbid patients.

The clinical management of BD-SUD subjects requires a careful distinction between mood and withdrawal/intoxication symptoms
$(126,127)$. Neuroimaging studies indicate that brain regions involved in mood regulation lie in close proximity to regions involved in motivation and craving (128). The complex interplay between addiction and BD domains, mediated by the involvement of similar neurobiological systems, requires further studies to better delineate how BD and SUD operate as reciprocal risk factors $(105,129)$. Recently, it has been proposed to focus on some clinical domain by using strategies aimed to treat both disorders simultaneously $(101,130)$. Besides reducing the recurrence of affective episodes, and exerting neuroprotective, mood stabilizers have been recently shown to have anti-anhedonic properties (131-134) with potential utility in the treatment of comorbid conditions (135141). In addition, glutamatergic agents have been demonstrated to be effective in the treatment of both mood (142) and addictive disorders $(82,143)$; furthermore, they have been recently proposed as a valuable therapeutic option in the treatment of comorbid patients (139).

Future studies aimed at assessing brain AL in patients with $\mathrm{BD}$ and addiction comorbidity may help to shed light on the complex interactions underlying neurobiological vulnerability to these disorders and to improve their treatment options. Early effective treatment strategies specifically devised for comorbid patients $(104,125)$ could prevent, or possibly reverse, some of the neurobiological abnormalities and indicators of AL, thus potentially leading to numerous benefits for these patients.

\section{REFERENCES}

1. Vornik LA, Brown ES. Management of comorbid bipolar disorder and substance abuse. J Clin Psychiatry (2006) 67(Suppl 7):24-30.

2. Grant BF, Stinson FS, Hasin DS, Dawson DA, Chou SP, Ruan WJ, et al. Prevalence, correlates, and comorbidity of bipolar I disorder and axis I and II disorders: results from the National Epidemiologic Survey on alcohol and related conditions. J Clin Psychiatry (2005) 66(10):1205-15. doi:10.4088/JCP. v66n1001

3. Altamura AC. Bipolar spectrum and drug addiction. J Affect Disord (2007) 99(1-3):285. doi:10.1016/j.jad.2006.09.005

4. Di Nicola M, Tedeschi D, Mazza M, Martinotti G, Harnic D, Catalano V, et al. Behavioural addictions in bipolar disorder patients: role of impulsivity and personality dimensions. J Affect Disord (2010) 125(1-3):82-8. doi:10.1016/j.jad.2009.12.016

5. Pettorruso M, Di Nicola M, De Risio L, Fasano A, Martinotti G, Conte G, et al. Punding behavior in bipolar disorder type 1: a case report. J Neuropsychiatry Clin Neurosci (2014) 26(4):E8-9. doi:10.1176/appi.neuropsych.13090217

6. Regier DA, Farmer ME, Rae DS, Locke BZ, Keith SJ, Judd LL, et al. Comorbidity of mental disorders with alcohol and other drug abuse. Results from the epidemiologic catchment area (ECA) study. JAMA (1990) 264(19):2511-8. doi:10.1001/jama.1990.03450190043026

7. Fagiolini A, Forgione R, Maccari M, Cuomo A, Morana B, Dell'Osso MC, et al. Prevalence, chronicity, burden and borders of bipolar disorder. J Affect Disord (2013) 148(2-3):161-9. doi:10.1016/j.jad.2013.02.001

8. Tsai HC, Lu MK, Yang YK, Huang MC, Yeh TL, Chen WJ, et al. Empirically derived subgroups of bipolar I patients with different comorbidity patterns of anxiety and substance use disorders in Han Chinese population. JAffect Disord (2012) 136(1-2):81-9. doi:10.1016/j.jad.2011.08.015

9. Frye MA, Salloum IM. Bipolar disorder and comorbid alcoholism: prevalence rate and treatment considerations. Bipolar Disord (2006) 8(6):677-85. doi:10.1111/j.1399-5618.2006.00370.x

10. Mazza M, Mandelli L, Di Nicola M, Harnic D, Catalano V, Tedeschi D, et al. Clinical features, response to treatment and functional outcome of bipolar disorder patients with and without co-occurring substance use disorder: 1-year followup. J Affect Disord (2009) 115(1-2):27-35. doi:10.1016/j.jad.2008.08.019

11. Mandelli L, Mazza M, Di Nicola M, Zaninotto L, Harnic D, Catalano V, et al. Role of substance abuse comorbidity and personality on the outcome of 
depression in bipolar disorder: harm avoidance influences medium-term treatment outcome. Psychopathology (2012) 45(3):174-8. doi:10.1159/000330364

12. McIntyre RS, Nguyen HT, Soczynska JK, Lourenco MT, Woldeyohannes HO, Konarski JZ. Medical and substance-related comorbidity in bipolar disorder: translational research and treatment opportunities. Dialogues Clin Neurosci (2008) 10(2):203-13.

13. Carrà G, Bartoli F, Crocamo C, Brady KT, Clerici M. Attempted suicide in people with co-occurring bipolar and substance use disorders: systematic review and meta-analysis. J Affect Disord (2014) 167:125-35. doi:10.1016/j.jad.2014. 05.066

14. Yoon YH, Chen CM, Yi HY, Moss HB. Effect of comorbid alcohol and drug use disorders on premature death among unipolar and bipolar disorder decedents in the United States, 1999 to 2006. Compr Psychiatry (2011) 52(5):453-64. doi:10.1016/j.comppsych.2010.10.005

15. Uhl GR, Drgon T, Johnson C, Li CY, Contoreggi C, Hess J, et al. Molecular genetics of addiction and related heritable phenotypes: genome-wide association approaches identify "connectivity constellation" and drug target genes with pleiotropic effects. Ann N Y Acad Sci (2008) 1141:318-81. doi:10.1196/annals.1441.018

16. Adida M, Jollant F, Clark L, Besnier N, Guillaume S, Kaladjian A, et al. Traitrelated decision-making impairment in the three phases of bipolar disorder. Biol Psychiatry (2011) 70(4):357-65. doi:10.1016/j.biopsych.2011.01.018

17. Adinoff B, Rilling LM, Williams MJ, Schreffler E, Schepis TS, Rosvall T, et al. Impulsivity, neural deficits, and the addictions: the "oops" factor in relapse. $J$ Addict Dis (2007) 26(Suppl 1):25-39. doi:10.1300/J069v26S01_04

18. Ahn WY, Rass O, Fridberg DJ, Bishara AJ, Forsyth JK, Breier A, et al. Temporal discounting of rewards in patients with bipolar disorder and schizophrenia. $J$ Abnorm Psychol (2011) 120(4):911-21. doi:10.1037/a0023333

19. Swann AC. The strong relationship between bipolar and substance-use disorder. Ann N Y Acad Sci (2010) 1187:276-93. doi:10.1111/j.1749-6632.2009. 05146.x

20. Sterling P, Eyer J. Allostasis: a new paradigm to explain arousal pathology. In: Fisher S, Reason J, editors. Handbook of Life Stress, Cognition and Health. Chichester: John Wiley (1988). p. 629-49.

21. McEwen BS. Stress, adaptation, and disease. Allostasis and allostatic load. Ann N Y Acad Sci (1998) 840:33-44. doi:10.1111/j.1749-6632.1998.tb09546.x

22. McEwen BS. Allostasis and allostatic load: implications for neuropsychopharmacology. Neuropsychopharmacology (2000) 22(2):108-24. doi:10. 1016/S0893-133X(99)00129-3

23. Brietzke E, Mansur RB, Soczynska J, Powell AM, McIntyre RS. A theoretical framework informing research about the role of stress in the pathophysiology of bipolar disorder. Prog Neuropsychopharmacol Biol Psychiatry (2012) 39(1):1-8. doi:10.1016/j.pnpbp.2012.05.004

24. Kapczinski F, Vieta E, Andreazza AC, Frey BN, Gomes FA, Tramontina J, et al. Allostatic load in bipolar disorder: implications for pathophysiology and treatment. Neurosci Biobehav Rev (2008) 32(4):675-92. doi:10.1016/j.neubiorev. 2007.10.005

25. Grande I, Magalhães PV, Kunz M, Vieta E, Kapczinski F. Mediators of allostasis and systemic toxicity in bipolar disorder. Physiol Behav (2012) 106(1):46-50. doi:10.1016/j.physbeh.2011.10.029

26. Vieta E, Popovic D, Rosa AR, Solé B, Grande I, Frey BN, et al. The clinical implications of cognitive impairment and allostatic load in bipolar disorder. Eur Psychiatry (2013) 28(1):21-9. doi:10.1016/j.eurpsy.2011.11.007

27. Angelucci F, Ricci V, Gelfo F, Martinotti G, Brunetti M, Sepede G, et al. BDNF serum levels in subjects developing or not post-traumatic stress disorder after trauma exposure. Brain $\operatorname{Cog} n$ (2014) 84(1):118-22. doi:10.1016/j.bandc.2013. 11.012

28. Kapczinski F, Frey BN, Kauer-Sant'Anna M, Grassi-Oliveira R. Brain-derived neurotrophic factor and neuroplasticity in bipolar disorder. Expert Rev Neurother (2008) 8(7):1101-13. doi:10.1586/14737175.8.7.1101

29. Mandelli L, Mazza M, Martinotti G, Tavian D, Colombo E, Missaglia S, et al. Further evidence supporting the influence of brain-derived neurotrophic factor on the outcome of bipolar depression: independent effect of brainderived neurotrophic factor and harm avoidance. J Psychopharmacol (2010) 24(12):1747-54. doi:10.1177/0269881109353463

30. Berk M, Kapczinski F, Andreazza AC, Dean OM, Giorlando F, Maes M, et al. Pathways underlying neuroprogression in bipolar disorder: focus on inflammation, oxidative stress and neurotrophic factors. Neurosci Biobehav Rev (2011) 35(3):804-17. doi:10.1016/j.neubiorev.2010.10.001
31. Grande I, Magalhães PV, Chendo I, Stertz L, Panizutti B, Colpo GD, et al. Staging systems in bipolar disorder: an International society for bipolar disorders task force report. Acta Psychiatr Scand (2014) 130(5):354-63. doi:10.1111/acps. 12268

32. Schulkin J. Allostasis: a neural behavioral perspective. Horm Behav (2003) 43(1):21-7. doi:10.1016/S0018-506X(02)00035-1

33. Swaab DF, Bao AM, Lucassen PJ. The stress system in the human brain in depression and neurodegeneration. Ageing Res Rev (2005) 4(2):141-94. doi:10.1016/j.arr.2005.03.003

34. Andreazza AC, Kauer-Sant'anna M, Frey BN, Bond DJ, Kapczinski F, Young LT, et al. Oxidative stress markers in bipolar disorder: a meta-analysis. J Affect Disord (2008) 111(2-3):135-44. doi:10.1016/j.jad.2008.04.013

35. Steen NE, Methlie P, Lorentzen S, Hope S, Barrett EA, Larsson S, et al. Increased systemic cortisol metabolism in patients with schizophrenia and bipolar disorder: a mechanism for increased stress vulnerability? J Clin Psychiatry (2011) 72(11):1515-21. doi:10.4088/JCP.10m06068yel

36. Steen NE, Methlie P, Lorentzen S, Dieset I, Aas M, Nerhus M, et al. Altered systemic cortisol metabolism in bipolar disorder and schizophrenia spectrum disorders. J Psychiatr Res (2014) 52:57-62. doi:10.1016/j.jpsychires. 2014.01.017

37. Daban C, Vieta E, Mackin P, Young AH. Hypothalamic-pituitary-adrenal axis and bipolar disorder. Psychiatr Clin North Am (2005) 28(2):469-80. doi:10.1016/j.psc.2005.01.005

38. Watson S, Gallagher P, Ritchie JC, Ferrier IN, Young AH. Hypothalamicpituitary-adrenal axis function in patients with bipolar disorder. Br J Psychiatry (2004) 184:496-502. doi:10.1192/bjp.184.6.496

39. McEwen BS. Structural plasticity of the adult brain: how animal models help us understand brain changes in depression and systemic disorders related to depression. Dialogues Clin Neurosci (2004) 6(2):119-33.

40. McEwen BS. Central effects of stress hormones in health and disease: understanding the protective and damaging effects of stress and stress mediators. Eur J Pharmacol (2008) 583(2-3):174-85. doi:10.1016/j.ejphar.2007.11.071

41. Altman S, Haeri S, Cohen LJ, Ten A, Barron E, Galynker II, et al. Predictors of relapse in bipolar disorder: a review. J Psychiatr Pract (2006) 12(5):269-82. doi:10.1097/00131746-200609000-00002

42. Horesh N, Apter A, Zalsman G. Timing, quantity and quality of stressful life events in childhood and preceding the first episode of bipolar disorder. JAffect Disord (2011) 134(1-3):434-7. doi:10.1016/j.jad.2011.05.034

43. Lai MC, Huang LT. Effects of early life stress on neuroendocrine and neurobehavior: mechanisms and implications. Pediatr Neonatol (2011) 52(3):122-9. doi:10.1016/j.pedneo.2011.03.008

44. Baker LM, Williams LM, Korgaonkar MS, Cohen RA, Heaps JM, Paul RH. Impact of early vs. late childhood early life stress on brain morphometrics. Brain Imaging Behav (2013) 7(2):196-203. doi:10.1007/s11682-012-9215-y

45. Linke J, King AV, Rietschel M, Strohmaier J, Hennerici M, Gass A, et al. Increased medial orbitofrontal and amygdala activation: evidence for a systems-level endophenotype of bipolar I disorder. Am J Psychiatry (2012) 169(3):316-25. doi:10.1176/appi.ajp.2011.11050711

46. Koob GF, Buck CL, Cohen A, Edwards S, Park PE, Schlosburg JE, et al. Addiction as a stress surfeit disorder. Neuropharmacology (2014) 76(Pt B):370-82. doi:10.1016/j.neuropharm.2013.05.024

47. Koob GF, Le Moal M. Drug addiction, dysregulation of reward, and allostasis. Neuropsychopharmacology (2001) 24(2):97-129. doi:10.1016/S0893-133X(00) 00195-0

48. Koob GF. Addiction is a reward deficit and stress surfeit disorder. Front Psychiatry (2013) 4:72. doi:10.3389/fpsyt.2013.00072

49. George O, Le Moal M, Koob GF. Allostasis and addiction: role of the dopamine and corticotropin-releasing factor systems. Physiol Behav (2012) 106(1):58-64. doi:10.1016/j.physbeh.2011.11.004

50. Koob G, Kreek MJ. Stress, dysregulation of drug reward pathways, and the transition to drug dependence. Am J Psychiatry (2007) 164(8):1149-59. doi:10.1176/appi.ajp.2007.05030503

51. Pettorruso M, Martinotti G, Fasano A, Loria G, Di Nicola M, De Risio L, et al. Anhedonia in Parkinson's disease patients with and without pathological gambling: a case-control study. Psychiatry Res (2014) 215(2):448-52. doi:10.1016/j.psychres.2013.12.013

52. Koob GF. Neurobiological substrates for the dark side of compulsivity in addiction. Neuropharmacology (2009) 56(Suppl 1):18-31. doi:10.1016/j. neuropharm.2008.07.043 
53. Gilpin NW. Brain reward and stress systems in addiction. Front Psychiatry (2014) 5:79. doi:10.3389/fpsyt.2014.00079

54. Koob GF. A role for brain stress systems in addiction. Neuron (2008) 59(1):11-34. doi:10.1016/j.neuron.2008.06.012

55. Koob GF, Le Moal M. Addiction and the brain antireward system. Annu Rev Psychol (2008) 59:29-53. doi:10.1146/annurev.psych.59.103006.093548

56. Koob GF. Hedonic homeostatic dysregulation as a driver of drug-seeking behavior. Drug Discov Today Dis Models (2008) 5(4):207-15. doi:10.1016/j. ddmod.2009.04.002

57. Koob GF. Neuroadaptive mechanisms of addiction: studies on the extended amygdala. Eur Neuropsychopharmacol (2003) 13(6):442-52. doi:10.1016/j. euroneuro.2003.08.005

58. Koob GF. The role of CRF and CRF-related peptides in the dark side of addiction. Brain Res (2010) 1314:3-14. doi:10.1016/j.brainres.2009.11.008

59. Martinotti G, Nicola MD, Reina D, Andreoli S, Focà F, Cunniff A, et al. Alcohol protracted withdrawal syndrome: the role of anhedonia. Subst Use Misuse (2008) 43(3-4):271-84. doi:10.1080/10826080701202429

60. Valdez GR, Koob GF. Allostasis and dysregulation of and neuropeptide Y systems: implications for the development of alcoholism. Pharmacol Biochem Behav (2004) 79(4):671-89. doi:10.1016/j.pbb.2004.09.020

61. Carmiol N, Peralta JM, Almasy L, Contreras J, Pacheco A, Escamilla MA, et al. Shared genetic factors influence risk for bipolar disorder and alcohol use disorders. Eur Psychiatry (2014) 29(5):282-7. doi:10.1016/j.eurpsy.2013. 10.001

62. Mandelli L, Mazza M, Marangoni C, Di Nicola M, Martinotti G, Tavian D, et al. Preliminary analysis of genes involved in inflammatory, oxidative processes and CA2+signaling in bipolar disorder and comorbidity for substance use disorder. Clin Neuropsychiatry (2011) 8(6):347-53.

63. Johnson C, Drgon T, McMahon FJ, Uhl GR. Convergent genome wide association results for bipolar disorder and substance dependence. Am J Med Genet B Neuropsychiatr Genet (2009) 150B(2):182-90. doi:10.1002/ajmg.b.30900

64. Levey DF, Le-Niculescu H, Frank J, Ayalew M, Jain N, Kirlin B, et al. Genetic risk prediction and neurobiological understanding of alcoholism. Transl Psychiatry (2014) 4:e391. doi:10.1038/tp.2014.29

65. Patel SD, Le-Niculescu H, Koller DL, Green SD, Lahiri DK, McMahon FJ, et al. Coming to grips with complex disorders: genetic risk prediction in bipolar disorder using panels of genes identified through convergent functional genomics. Am J Med Genet B Neuropsychiatr Genet (2010) 153B(4):850-77. doi:10.1002/ajmg.b.31087

66. Haldane M, Frangou S. New insights help define the pathophysiology of bipolar affective disorder: neuroimaging and neuropathology findings. Prog Neuropsychopharmacol Biol Psychiatry (2004) 28(6):943-60. doi:10.1016/j.pnpbp.2004. 05.040

67. Wallis JD, Miller EK. Neuronal activity in primate dorsolateral and orbital prefrontal cortex during performance of a reward preference task. Eur J Neurosci (2003) 18(7):2069-81. doi:10.1046/j.1460-9568.2003.02922.x

68. Frangou S, Kington J, Raymont V, Shergill SS. Examining ventral and dorsal prefrontal function in bipolar disorder: a functional magnetic resonance imaging study. Eur Psychiatry (2008) 23(4):300-8. doi:10.1016/j.eurpsy.2007. 05.002

69. Jogia J, Dima D, Kumari V, Frangou S. Frontopolar cortical inefficiency may underpin reward and working memory dysfunction in bipolar disorder. World J Biol Psychiatry (2012) 13(8):605-15. doi:10.3109/15622975.2011.585662

70. Young JW, van Enkhuizen J, Winstanley CA, Geyer MA. Increased risktaking behavior in dopamine transporter knockdown mice: further support for a mouse model of mania. J Psychopharmacol (2011) 25(7):934-43. doi:10.1177/0269881111400646

71. Camardese G, Di Giuda D, Di Nicola M, Cocciolillo F, Giordano A, Janiri L, et al. Imaging studies on dopamine transporter and depression: a review of literature and suggestions for future research. J Psychiatr Res (2014) 51:7-18. doi:10.1016/j.jpsychires.2013.12.006

72. Comings DE, Rosenthal RJ, Lesieur HR, Rugle LJ, Muhleman D, Chiu C, et al. A study of the dopamine D2 receptor gene in pathological gambling. Pharmacogenetics (1996) 6(3):223-34. doi:10.1097/00008571-199606000-00004

73. van Enkhuizen J, Geyer MA, Young JW. Differential effects of dopamine transporter inhibitors in the rodent Iowa gambling task: relevance to mania. Psychopharmacology (Berl) (2013) 225(3):661-74. doi:10.1007/s00213-0122854-2
74. van Enkhuizen J, Henry BL, Minassian A, Perry W, Milienne-Petiot M, Higa KK, et al. Reduced dopamine transporter functioning induces high-reward riskpreference consistent with bipolar disorder. Neuropsychopharmacology (2014) 39(13):3112-22. doi:10.1038/npp.2014.170

75. Berk M, Dodd S, Kauer-Sant'anna M, Malhi GS, Bourin M, Kapczinski F, et al. Dopamine dysregulation syndrome: implications for a dopamine hypothesis of bipolar disorder. Acta Psychiatr Scand Suppl (2007) 434:41-9. doi:10.1111/j.1600-0447.2007.01058.x

76. Cousins DA, Butts K, Young AH. The role of dopamine in bipolar disorder. Bipolar Disord (2009) 11(8):787-806. doi:10.1111/j.1399-5618.2009. 00760.x

77. Diana M. The dopamine hypothesis of drug addiction and its potential therapeutic value. Front Psychiatry (2011) 2:64. doi:10.3389/fpsyt.2011.00064

78. Der-Avakian A, Markou A. The neurobiology of anhedonia and other rewardrelated deficits. Trends Neurosci (2012) 35(1):68-77. doi:10.1016/j.tins.2011. 11.005

79. Hatzigiakoumis DS, Martinotti G, Giannantonio MD, Janiri L. Anhedonia and substance dependence: clinical correlates and treatment options. Front Psychiatry (2011) 2:10. doi:10.3389/fpsyt.2011.00010

80. Kirby LG, Zeeb FD, Winstanley CA. Contributions of serotonin in addiction vulnerability. Neuropharmacology (2011) 61(3):421-32. doi:10.1016/j. neuropharm.2011.03.022

81. Van den Oever MC, Spijker S, Smit AB. The synaptic pathology of drug addiction. Adv Exp Med Biol (2012) 970:469-91. doi:10.1007/978-3-70910932-8_21

82. Pettorruso M, De Risio L, Martinotti G, Di Nicola M, Ruggeri F, Conte G, et al. Targeting the glutamatergic system to treat pathological gambling: current evidence and future perspectives. Biomed Res Int (2014) 2014:109786. doi:10.1155/2014/109786

83. Pettorruso M, Martinotti G, Di Nicola M, Onofrj M, Di Giannantonio M, Conte $\mathrm{G}$, et al. Amantadine in the treatment of pathological gambling: a case report. Front Psychiatry (2012) 3:102. doi:10.3389/fpsyt.2012.00102

84. Di Nicola M, De Risio L, Battaglia C, Camardese G, Tedeschi D, Mazza M, et al. Reduced hedonic capacity in euthymic bipolar subjects: a trait-like feature? J Affect Disord (2013) 147(1-3):446-50. doi:10.1016/j.jad.2012.10.004

85. McIntyre RS, McElroy SL, Konarski JZ, Soczynska JK, Bottas A, Castel S, et al. Substance use disorders and overweight/obesity in bipolar I disorder: preliminary evidence for competing addictions. JClin Psychiatry (2007) 68(9):1352-7. doi:10.4088/JCP.v68n0905

86. Ibanez A, Cetkovich M, Petroni A, Urquina H, Baez S, Gonzalez-Gadea ML, et al. The neural basis of decision-making and reward processing in adults with euthymic bipolar disorder or attention-deficit/hyperactivity disorder (ADHD). PLoS One (2012) 7(5):e37306. doi:10.1371/journal.pone.0037306

87. Strakowski SM, Fleck DE, DelBello MP, Adler CM, Shear PK, Kotwal R, et al. Impulsivity across the course of bipolar disorder. Bipolar Disord (2010) 12(3):285-97. doi:10.1111/j.1399-5618.2010.00806.x

88. Pizzagalli DA, Goetz E, Ostacher M, Iosifescu DV, Perlis RH. Euthymic patients with bipolar disorder show decreased reward learning in a probabilistic reward task. Biol Psychiatry (2008) 64(2):162-8. doi:10.1016/j.biopsych.2007. 12.001

89. Chandler RA, Wakeley J, Goodwin GM, Rogers RD. Altered risk-aversion and risk-seeking behavior in bipolar disorder. Biol Psychiatry (2009) 66(9):840-6. doi:10.1016/j.biopsych.2009.05.011

90. Mason L, O’Sullivan N, Blackburn M, Bentall R, El-Deredy W. I want it now! neural correlates of hypersensitivity to immediate reward in hypomania. Biol Psychiatry (2012) 71(6):530-7. doi:10.1016/j.biopsych.2011.10.008

91. Bizzarri JV, Sbrana A, Rucci P, Ravani L, Massei GJ, Gonnelli C, et al. The spectrum of substance abuse in bipolar disorder: reasons for use, sensation seeking and substance sensitivity. Bipolar Disord (2007) 9(3):213-20. doi:10.1111/j.1399-5618.2007.00383.x

92. Edge MD, Miller CJ, Muhtadie L, Johnson SL, Carver CS, Marquinez N, et al. People with bipolar I disorder report avoiding rewarding activities and dampening positive emotion. J Affect Disord (2013) 146(3):407-13. doi:10.1016/j.jad.2012.07.027

93. Nusslock R, Almeida JR, Forbes EE, Versace A, Frank E, Labarbara EJ, et al. Waiting to win: elevated striatal and orbitofrontal cortical activity during reward anticipation in euthymic bipolar disorder adults. Bipolar Disord (2012) 14(3):249-60. doi:10.1111/j.1399-5618.2012.01012.x 
94. Linke J, Sonnekes C, Wessa M. Sensitivity to positive and negative feedback in euthymic patients with bipolar I disorder: the last episode makes the difference. Bipolar Disord (2011) 13(7-8):638-50. doi:10.1111/j.1399-5618.2011.00956.x

95. Yechiam E, Hayden EP, Bodkins M, O’Donnell BF, Hetrick WP. Decision making in bipolar disorder: a cognitive modeling approach. Psychiatry Res (2008) 161(2):142-52. doi:10.1016/j.psychres.2007.07.001

96. Pizzagalli DA. Depression, stress, and anhedonia: toward a synthesis and integrated model. Annu Rev Clin Psychol (2014) 10:393-423. doi:10.1146/annurevclinpsy-050212-185606

97. Sinha R. Chronic stress, drug use, and vulnerability to addiction. Ann N Y Acad Sci (2008) 1141:105-30. doi:10.1196/annals.1441.030

98. Lovallo WR. Cortisol secretion patterns in addiction and addiction risk. Int J Psychophysiol (2006) 59(3):195-202. doi:10.1016/j.ijpsycho.2005.10.007

99. Lijffijt M, Hu K, Swann AC. Stress modulates illness-course of substance use disorders: a translational review. Front Psychiatry (2014) 5:83. doi:10.3389/ fpsyt.2014.00083

100. Levy YZ, Levy DJ, Barto AG, Meyer JS. A computational hypothesis for allostasis: delineation of substance dependence, conventional therapies, and alternative treatments. Front Psychiatry (2013) 4:167. doi:10.3389/fpsyt.2013.00167

101. Post RM, Kalivas P. Bipolar disorder and substance misuse: pathological and therapeutic implications of their comorbidity and cross-sensitisation. Br J Psychiatry (2013) 202(3):172-6. doi:10.1192/bjp.bp.112.116855

102. Azorin JM, Bellivier F, Kaladjian A, Adida M, Belzeaux R, Fakra E, et al. Characteristics and profiles of bipolar I patients according to age-at-onset: findings from an admixture analysis. J Affect Disord (2013) 150(3):993-1000. doi:10.1016/j.jad.2013.05.026

103. Pope MA, Joober R, Malla AK. Diagnostic stability of first-episode psychotic disorders and persistence of comorbid psychiatric disorders over 1 year. Can J Psychiatry (2013) 58(10):588-94.

104. Goldstein BI, Strober M, Axelson D, Goldstein TR, Gill MK, Hower H, et al. Predictors of first-onset substance use disorders during the prospective course of bipolar spectrum disorders in adolescents. J Am Acad Child Adolesc Psychiatry (2013) 52(10):1026-37. doi:10.1016/j.jaac.2013.07.009

105. Kenneson A, Funderburk JS, Maisto SA. Risk factors for secondary substance use disorders in people with childhood and adolescent-onset bipolar disorder: opportunities for prevention. Compr Psychiatry (2013) 54(5):439-46. doi:10.1016/j.comppsych.2012.12.008

106. Duffy A, Horrocks J, Milin R, Doucette S, Persson G, Grof P. Adolescent substance use disorder during the early stages of bipolar disorder: a prospective high-risk study. J Affect Disord (2012) 142(1-3):57-64. doi:10.1016/j.jad.2012. 04.010

107. Do EK, Mezuk B. Comorbidity between hypomania and substance use disorders. J Affect Disord (2013) 150(3):974-80. doi:10.1016/j.jad.2013.05.023

108. Prisciandaro JJ, DeSantis SM, Chiuzan C, Brown DG, Brady KT, Tolliver BK. Impact of depressive symptoms on future alcohol use in patients with cooccurring bipolar disorder and alcohol dependence: a prospective analysis in an 8-week randomized controlled trial of acamprosate. Alcohol Clin Exp Res (2012) 36(3):490-6. doi:10.1111/j.1530-0277.2011.01645.x

109. Saddichha S, Prakash R, Sinha BN, Khess CR. Perceived reasons for and consequences of substance abuse among patients with psychosis. Prim Care Companion J Clin Psychiatry (2010) 12(5):e1-7. doi:10.4088/PCC.09m00926gry

110. Pettersen H, Ruud T, Ravndal E, Landheim A. Walking the fine line: selfreported reasons for substance use in persons with severe mental illness. Int J Qual Stud Health Well-being (2013) 8:21968. doi:10.3402/qhw.v8i0.21968

111. Rømer Thomsen K, Callesen MB, Linnet J, Kringelbach ML, Møller A. Severity of gambling is associated with severity of depressive symptoms in pathological gamblers. Behav Pharmacol (2009) 20(5-6):527-36. doi:10.1097/FBP. 0b013e3283305e7a

112. Khantzian EJ. The self-medication hypothesis of addictive disorders: focus on heroin and cocaine dependence. Am J Psychiatry (1985) 142(11):1259-64.

113. Robinson LJ, Thompson JM, Gallagher P, Goswami U, Young AH, Ferrier IN, et al. A meta-analysis of cognitive deficits in euthymic patients with bipolar disorder. J Affect Disord (2006) 93(1-3):105-15. doi:10.1016/j.jad.2006.02.016

114. Bally N, Zullino D, Aubry JM. Cannabis use and first manic episode. J Affect Disord (2014) 165:103-8. doi:10.1016/j.jad.2014.04.038

115. Lev-Ran S, Le Foll B, McKenzie K, George TP, Rehm J. Bipolar disorder and cooccurring cannabis use disorders: characteristics, co-morbidities and clinical correlates. Psychiatry Res (2013) 209(3):459-65. doi:10.1016/j.psychres.2012. 12.014

116. Baigent M. Managing patients with dual diagnosis in psychiatric practice. Curr Opin Psychiatry (2012) 25(3):201-5. doi:10.1097/YCO.0b013e3283523d3d

117. Di Nicola M, Sala L, Romo L, Catalano V, Even C, Dubertret C, et al. Adult attention-deficit/hyperactivity disorder in major depressed and bipolar subjects: role of personality traits and clinical implications. Eur Arch Psychiatry Clin Neurosci (2014) 264(5):391-400. doi:10.1007/s00406-013-0456-6

118. Perugi G, Ceraudo G, Vannucchi G, Rizzato S, Toni C, Dell'Osso L. Attention deficit/hyperactivity disorder symptoms in Italian bipolar adult patients: a preliminary report. JAffect Disord (2013) 149(1-3):430-4. doi:10.1016/j.jad.2012. 12.010

119. Sala R, Goldstein BI, Wang S, Blanco C. Childhood maltreatment and the course of bipolar disorders among adults: epidemiologic evidence of dose-response effects. J Affect Disord (2014) 165:74-80. doi:10.1016/j.jad.2014.04.035

120. Jones SH, Barrowclough C, Allott R, Day C, Earnshaw P, Wilson I. Integrated motivational interviewing and cognitive-behavioural therapy for bipolar disorder with comorbid substance use. Clin Psychol Psychother (2011) 18(5):426-37. doi:10.1002/cpp.783

121. Gaudiano BA, Weinstock LM, Miller IW. Improving treatment adherence in patients with bipolar disorder and substance abuse: rationale and initial development of a novel psychosocial approach. J Psychiatr Pract (2011) 17(1):5-20. doi:10.1097/01.pra.0000393840.18099.d6

122. Horsfall J, Cleary M, Hunt GE, Walter G. Psychosocial treatments for people with co-occurring severe mental illnesses and substance use disorders (dual diagnosis): a review of empirical evidence. Harv Rev Psychiatry (2009) 17(1):24-34. doi:10.1080/10673220902724599

123. Murru A, Pacchiarotti I, Amann BL, Nivoli AM, Vieta E, Colom F. Treatment adherence in bipolar I and schizoaffective disorder, bipolar type. J Affect Disord (2013) 151(3):1003-8. doi:10.1016/j.jad.2013.08.026

124. Juster RP, McEwen BS, Lupien SJ. Allostatic load biomarkers of chronic stress and impact on health and cognition. Neurosci Biobehav Rev (2010) 35(1):2-16. doi:10.1016/j.neubiorev.2009.10.002

125. Goldstein BI, Bukstein OG. Comorbid substance use disorders among youth with bipolar disorder: opportunities for early identification and prevention. $J$ Clin Psychiatry (2010) 71(3):348-58. doi:10.4088/JCP.09r05222gry

126. Langas AM, Malt UF, Opjordsmoen S. Independent versus substance-induced major depressive disorders in first-admission patients with substance use disorders: an exploratory study. J Affect Disord (2013) 144(3):279-83. doi:10.1016/ j.jad.2012.10.008

127. Quello SB, Brady KT, Sonne SC. Mood disorders and substance use disorder: a complex comorbidity. Sci Pract Perspect (2005) 3(1):13-21. doi:10.1151/ spp053113

128. Li CS, Sinha R. Inhibitory control and emotional stress regulation: neuroimaging evidence for frontal-limbic dysfunction in psycho-stimulant addiction. Neurosci Biobehav Rev (2008) 32(3):581-97. doi:10.1016/j.neubiorev.2007.10. 003

129. Kenneson A, Funderburk JS, Maisto SA. Substance use disorders increase the odds of subsequent mood disorders. Drug Alcohol Depend (2013) 133(2):338-43. doi:10.1016/j.drugalcdep.2013.06.011

130. Pettinati HM, O'Brien CP, Dundon WD. Current status of co-occurring mood and substance use disorders: a new therapeutic target. Am J Psychiatry (2013) 170(1):23-30. doi:10.1176/appi.ajp.2012.12010112

131. Marchese G, Scheggi S, Secci ME, De Montis MG, Gambarana C. Antianhedonic activity of long-term lithium treatment in rats exposed to repeated unavoidable stress. Int J Neuropsychopharmacol (2013) 16(7):1611-21. doi:10. 1017/S1461145712001654

132. Orsetti M, Canonico PL, Dellarole A, Colella L, Di Brisco F, Ghi P. Quetiapine prevents anhedonia induced by acute or chronic stress. Neuropsychopharmacology (2007) 32(8):1783-90. doi:10.1038/sj.npp.1301291

133. Marston HM, Martin FD, Papp M, Gold L, Wong EH, Shahid M. Attenuation of chronic mild stress-induced 'anhedonia' by asenapine is not associated with a 'hedonic' profile in intracranial self-stimulation. J Psychopharmacol (2011) 25(10):1388-98. doi:10.1177/0269881110376684

134. Mazza M, Squillacioti MR, Pecora RD, Janiri L, Bria P. Effect of aripiprazole on self-reported anhedonia in bipolar depressed patients. Psychiatry Res (2009) 165(1-2):193-6. doi:10.1016/j.psychres.2008.05.003 
135. Martinotti G, Andreoli S, Di Nicola M, Di Giannantonio M, Sarchiapone M, Janiri L. Quetiapine decreases alcohol consumption, craving, and psychiatric symptoms in dually diagnosed alcoholics. Hum Psychopharmacol (2008) 23(5):417-24. doi:10.1002/hup.944

136. Prisciandaro JJ, Brown DG, Brady KT, Tolliver BK. Comorbid anxiety disorders and baseline medication regimens predict clinical outcomes in individuals with co-occurring bipolar disorder and alcohol dependence: results of a randomized controlled trial. Psychiatry Res (2011) 188(3):361-5. doi:10.1016/j. psychres.2011.04.030

137. Di Nicola M, Martinotti G, Mazza M, Tedeschi D, Pozzi G, Janiri L. Quetiapine as add-on treatment for bipolar I disorder with comorbid compulsive buying and physical exercise addiction. Prog Neuropsychopharmacol Biol Psychiatry (2010) 34(4):713-4. doi:10.1016/j.pnpbp.2010.03.013

138. Janiri L, Martinotti G, Di Nicola M. Aripiprazole for relapse prevention and craving in alcohol-dependent subjects: results from a pilot study. J Clin Psychopharmacol (2007) 27(5):519-20. doi:10.1097/JCP.0b013e318150c841

139. Di Nicola M, De Risio L, Pettorruso M, Caselli G, De Crescenzo F, SwierkoszLenart $\mathrm{K}$, et al. Bipolar disorder and gambling disorder comorbidity: current evidence and implications for pharmacological treatment. J Affect Disord (2014) 167:285-98. doi:10.1016/j.jad.2014.06.023

140. Beaulieu S, Saury S, Sareen J, Tremblay J, Schütz CG, McIntyre RS, et al. The canadian network for mood and anxiety treatments (CANMAT) task force recommendations for the management of patients with mood disorders and comorbid substance use disorders. Ann Clin Psychiatry (2012) 24(1):38-55.

141. Sani G, Kotzalidis GD, Vöhringer P, Pucci D, Simonetti A, Manfredi G, et al. Effectiveness of short-term olanzapine in patients with bipolar I disorder, with or without comorbidity with substance use disorder. J Clin Psychopharmacol (2013) 33(2):231-5. doi:10.1097/JCP.0b013e318287019c

142. Machado-Vieira R, Ibrahim L, Henter ID, Zarate CA Jr. Novel glutamatergic agents for major depressive disorder and bipolar disorder. Pharmacol Biochem Behav (2012) 100(4):678-87. doi:10.1016/j.pbb.2011.09.010

143. Olive MF, Cleva RM, Kalivas PW, Malcolm RJ. Glutamatergic medications for the treatment of drug and behavioral addictions. Pharmacol Biochem Behav (2012) 100(4):801-10. doi:10.1016/j.pbb.2011.04.015

Conflict of Interest Statement: The authors declare that the research was conducted in the absence of any commercial or financial relationships that could be construed as a potential conflict of interest.

Received: 31 March 2014; accepted: 16 November 2014; published online: 03 December 2014.

Citation: Pettorruso M, De Risio L, Di Nicola M, Martinotti G, Conte G and Janiri $L$ (2014) Allostasis as a conceptual framework linking bipolar disorder and addiction. Front. Psychiatry 5:173. doi: 10.3389/fpsyt.2014.00173

This article was submitted to Addictive Disorders and Behavioral Dyscontrol, a section of the journal Frontiers in Psychiatry.

Copyright (c) 2014 Pettorruso, De Risio, Di Nicola, Martinotti, Conte and Janiri. This is an open-access article distributed under the terms of the Creative Commons Attribution License (CC BY). The use, distribution or reproduction in other forums is permitted, provided the original author(s) or licensor are credited and that the original publication in this journal is cited, in accordance with accepted academic practice. No use, distribution or reproduction is permitted which does not comply with these terms. 